\title{
Biometric analysis of arabica coffee grown in low potassium nutrient solution under greenhouse conditions
}

\author{
W.M. Moura1', Y.J.B. Soares², A.T. Amaral Júnior ${ }^{3}$, G.A. Gravina ${ }^{3}$, \\ L.D. Barili ${ }^{4}$ and H.D. Vieira ${ }^{3}$ \\ ${ }^{1}$ Empresa Pesquisa Agropecuária de Minas Gerais, EPAMIG Sudeste, Viçosa, \\ MG, Brasil \\ ${ }^{2}$ Comissão Executiva do Plano da Lavoura Cacaueira, Ilhéus, BA, Brasil \\ ${ }^{3}$ Universidade Estadual Norte Fluminense Darcy Ribeiro, \\ Campos dos Goytacazes, RJ, Brasil \\ ${ }^{4}$ Universidade Federal de Viçosa, Viçosa, MG, Brasil \\ Corresponding author: W.M. Moura \\ E-mail: waldenia@epamig.ufv.br \\ Genet. Mol. Res. 15 (3): gmr.15038753 \\ Received May 3, 2016 \\ Accepted June 7, 2016 \\ Published September 19, 2016 \\ DOI http://dx.doi.org/10.4238/gmr.15038753
}

Copyright (C 2016 The Authors. This is an open-access article distributed under the terms of the Creative Commons Attribution ShareAlike (CC BY-SA) 4.0 License.

\begin{abstract}
Genetic parameters and associations between morphoagronomic traits and nutritional efficiencies of arabica coffee cultivars were estimated to identify promising traits to assist in the selection of coffee genotypes efficient in potassium use, under limiting conditions of this nutrient. The experiment was conducted in a greenhouse with 20 arabica coffee cultivars grown in nutrient solution with a low potassium level $(1.5 \mathrm{mM})$, using a randomized block design with three replicates. The traits evaluated were plant height, number of leaves, number of nodes, internode length, stem diameter, leaf area, rooting efficiency, potassium absorption efficiency, potassium translocation efficiency,
\end{abstract}


biomass production efficiency, and potassium use efficiency. Genetic variability among coffee cultivars for all the evaluated traits was found. The phenotypic variance for all traits showed a higher contribution of genetic variance compared to environmental variance. Plant height, internode length, stem diameter, leaf area, biomass production efficiency, and potassium use efficiency had a genotypic determination coefficient $\left(\mathrm{H}^{2}\right)$ above $80 \%$ and variation index greater than one. Leaf area and stem diameter had significant and positive genetic correlations with rooting, biomass production, and potassium use efficiencies. Stem diameter has great potential for use in breeding programs with a goal of indirect selection of cultivars that have greater potassium use efficiency in environments with restrictions of this nutrient.

Key words: Coffea arabica; Biometrics; Selection process; Mineral nutrition; Plant breeding; Genetic variability

\section{INTRODUCTION}

Brazilian coffee cultivation has global economic importance. Brazil is the largest producer and exporter of coffee, accounting for about one third of production and exports worldwide (OECD/FAO, 2015). Two coffee species, Coffea canephora and C. arabica, are cultivated in Brazil; the latter has a cultivated area of 1.77 million hectares and an estimated production of 31.3 million bags, representing $74 \%$ of the total production in the country (CONAB, 2015). This high yield results from the use of new cultivars obtained in breeding programs, as well as to the adoption of different management techniques, such as the use of chemical fertilizers. In general, cultivars are planted in highly weathered soils with low fertility presenting acute nutrient deficiencies, such as potassium, calcium, and magnesium, requiring high amounts of mineral fertilizers, which account for about $40 \%$ of production costs (MAPA, 2012).

Potassium, which is a non-renewable natural resource, is used in the fertilization of crops in the form of potassium chloride leading to very high production costs (Nogueira et al., 2001; Ernani et al., 2007). This element is the second most important nutrient for cultivated coffee because it is involved in the synthesis of proteins, carbohydrates, and adenosine triphosphate (ATP); in osmotic regulation; in tolerance to pests and diseases through increased resistance; and in the permeability of plasma membranes (Ernani et al., 2007; Marschner, 2012). It also influences the reproductive development of coffee, fruit production, and height (Laviola et al., 2006; Clemente et al., 2013). Further, it contributes to beverage quality by enabling the polyphenol oxidase enzyme to be present in the coffee fruit (Guimarães et al., 2011). Thus, alternatives that may contribute to the sustainability of coffee cultivation in Brazilian soils are of great importance, such as studies involving mineral nutrition and breeding, in order to select the most efficient plants in potassium use (Moura et al., 2015).

Breeding for desirable nutritional traits is, with rare exceptions, a complex process, often with quantitative inheritance, and is greatly affected by environmental factors. Nevertheless, variability in the nutritional efficiency between coffee genotypes has been observed in relation to morpho-agronomic traits and absorption, translocation, and use capacity of nutrients when grown in environments with low Zn (Reis Jr and Martinez, 2002; Zabini et al., 2007; Pedrosa et

Genetics and Molecular Research 15 (3): gmr.15038753 
al., 2013), Mn (Zabini et al., 2007), or with low levels of fertilization (Amaral et al., 2011a,b). In breeding programs with a goal of adaptation of plants to low nutrient availability, estimation of genetic parameters of traits related to tolerance to nutritional stress allows a better understanding of the genetic structure of the population. This is essential for predicting genetic gains and for the possible success of selection (Cruz et al., 2012). However, in coffee cultivation, these studies have mainly been carried out under conditions of sufficient nutrient availability for morpho-agronomic traits and nutritional efficiencies (Bonomo et al., 2004; Freitas et al., 2007; Ivoglo et al., 2008; Carvalho et al., 2010; Rodrigues et al., 2012); therefore, studies under nutrient stress conditions are necessary.

Another fact to consider in nutrient restriction studies is the genetic correlation, because the nutritional efficiency indices are obtained by processes that destroy the plant and are cost effective, which hinders the advancement of generations and advances in breeding. Estimating the relationship between pairs of morpho-agronomic traits with nutritional efficiencies contributes significantly to the selection process. This association allows indirect selection of desirable traits based on correlated traits that are easier to evaluate and have high heritability, promoting greater selection gains with savings of time, labor, and resources (Ferrão et al., 2008).

Although rare, studies with the goal of adapting coffee plants to environments with $\mathrm{K}$ restriction are necessary because of the importance of this nutrient to the culture's development, reduction in production costs, and preservation of the environment. Thus, the objective of this study was to estimate genetic parameters and associations between morpho-agronomic traits and nutritional efficiencies to identify promising traits to assist in selecting coffee genotypes, which are efficient in potassium use when this nutrient is limited.

\section{MATERIAL AND METHODS}

\section{Preparation and conduction of the experiment}

The experiment was conducted in a Federal University of Viçosa, Minas Gerais at the Plant Science Department (DFT) greenhouse. We evaluated 20 arabica coffee cultivars (Table $1)$, grown in static aerated nutrient solution containing low potassium $(1.5 \mathrm{mM})$.

Seedlings were cultivated in $25 \times 35-\mathrm{cm}$ plastic trays with $4-\mathrm{mm}$ holes in the bottom filled with sand purified with $0.1 \mathrm{~N} \mathrm{HCl}$. In each tray, 65 seeds were placed without parchment. When the seedlings reached the stage of "ear jaguar", the two most vigorous were transplanted into plastic containers containing 8.0 L of Hoagland and Arnon (1950) nutrient solution. A Schultz compressor was used to oxygenate the nutrient solution. The solution volume in the containers was brought to a final volume of $8.0 \mathrm{~L}$ with deionized water. The $\mathrm{pH}$ was maintained at 5.5-6.5 with $\mathrm{HCl}(1.0 \mathrm{~N})$ and $\mathrm{NaOH}(1.0 \mathrm{~N})$. The solutions were replaced when the initial electrical conductivity was depleted by $30 \%$. The nutrient solution was replaced twice.

The experimental design was a randomized block with three replicates. The plots consisted of two plants grown in pots with nutrient solution.

The agronomic characteristics evaluated included: plant height $(\mathrm{PH})$, measured from the base of the orthotropic branch to the plant apex in meters; number of leaves (NL) in the whole plant; number of nodes (NNO) in the orthotropic branch; stem diameter (SD), measured using digital calipers at the base of the orthotropic branch in mm; leaf area (LA) based on the total number of leaves, using a calibrated leaf area meter (Delta-T Devices Ltd., Burwell, Cambridge); and internode length (IL), which is the ratio of plant height:number of nodes.

Genetics and Molecular Research 15 (3): gmr.15038753 
Table 1. List of the cultivars, genealogy, and coffee plant height (Coffea arabica L.) evaluated in the experiment.

\begin{tabular}{|c|c|c|}
\hline Cultivars & Genealogy & Height \\
\hline 1 - Catuaí Amarelo IAC 62 & Caturra Amarelo IAC 476-11 × Mundo Novo IAC 374-19 & Low \\
\hline 2 - Paraíso MG H 419-1 & Caturra Amarelo IAC $30 \times$ Híbrido de Timor UFV 445-46 & Low \\
\hline 3 - Icatu Vermelho IAC 4045 & Coffea canefhora $\times$ Bourbon Vermelho & High \\
\hline 4 - Obatã IAC 1669/20 & Villa Sarchi $\times$ Híbrido de Timor & Low \\
\hline 5 - Caturra Amarelo & Mutação do Caturra Vermelho & Low \\
\hline 6 - IPR 102 & Icatu $\times$ Catuaí & Low \\
\hline 7 - Catuaí Vermelho IAC 15 & Caturra Amarelo IAC 476-11 × Mundo Novo & Low \\
\hline 8 - Rubi MG 1192 & Catuaí $\times$ Mundo Novo & Low \\
\hline 9 - IPR 103 & Icatu $\times$ Catuaí & Low \\
\hline 10 - Araponga MG1 & Caturra Amarelo IAC $86 \times$ Híbrido de Timor UFV 446-08 & Low \\
\hline 11 - Topázio MG 1190 & Catuaí Amarelo $\times$ Novo Mundo & Low \\
\hline 12 - San Ramon & - & Low \\
\hline 13 - Icatu Precoce 3282 & Icatu Vermelho $\times$ Bourbon Amarelo & High \\
\hline 14 - Tupi IAC 1669-33 & Villa Sarchi $\times$ Híbrido de Timor & Low \\
\hline 15 - Catucaí $785 / 15$ & Icatu Vermelho $\times$ Catuaí Vermelho & Low \\
\hline 16 - Acaiá Cerrado MG 1474 & Seleção de Mundo Novo & High \\
\hline 17 - Oeiras MG 6851 & Híbrido CIFC HW 26/5 (Caturra Vermelho × Híbrido de Timor) & Low \\
\hline 18 - São Bernardo & 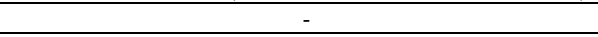 & Low \\
\hline 19 - Pau Brasil MG1 & Catuaí Vermelho IAC $15 \times$ Híbrido de Timor UFV 442/34 & Low \\
\hline 20 - Caturra Vermelho & Mutação de Bourbon Vermelho & Low \\
\hline
\end{tabular}

The plants were separated into roots, stems, and leaves, and dried in an oven with forced air circulation at $70^{\circ} \mathrm{C}$ for $72 \mathrm{~h}$. Root dry mass, stem dry mass, and leaf dry mass were determined. Dry plant materials were ground using a Wiley mill, to pass through a 20-mesh sieve, and samples were analyzed at the Leaf Analysis Laboratory of the Federal University of Viçosa (UFV) to determine the nutrient levels.

The $\mathrm{K}$ levels in the plant parts were used to determine $\mathrm{K}$ contents by multiplying the $\mathrm{K}$ levels by the dry mass of each plant part. The utilization efficiency indices were estimated on the basis of dry mass and K levels, according to Siddiqi and Glass (1981): a) rooting efficiency $(\mathrm{RE})=(\mathrm{g} \text { root dry matter })^{2} / \mathrm{mg} \mathrm{K}$ in the plant; $\left.\mathrm{b}\right)$ potassium absorption efficiency $(\mathrm{KAE})=$ $\mathrm{mg} \mathrm{K}$ in the plant/g root dry matter; c) potassium translocation efficiency (KTE) $=\mathrm{mg} \mathrm{K}$ in the aerial part/mg K in the plant; d) biomass production efficiency $(\mathrm{BE})=(\mathrm{g}$ dry matter of the aerial part $)^{2} / \mathrm{mg} \mathrm{K}$ in the aerial part; and e) potassium utilization efficiency (KUE) $=(\mathrm{g}$ dry matter $)^{2} / \mathrm{mg} \mathrm{K}$ in the plant.

\section{Statistical analysis}

Data were subjected to analysis of variance, and for each trait, the following genetic parameters were estimated: a) phenotypic variance, represented by the ratio of the genotype mean square $(Q M G)$ and the number of replications $\left.(b): \hat{\sigma}_{f}^{2}=Q M G / b ; \mathrm{b}\right)$ environmental variance, represented by the residue mean square $\left.(Q M R): \hat{\sigma}_{A}^{2}=Q M R ; \mathrm{c}\right)$ genotypic variance: $\left.\hat{\Phi}_{G}=\frac{Q M G-Q M R}{b} ; \mathrm{d}\right)$ coefficient of genotypic determination, obtained by the ratio between the estimates of genotypic variability: $\left(\hat{\Phi}_{G}\right)$ phenotypic variance $\left(\hat{\sigma}_{f}^{2}\right): \hat{H}^{2}=\hat{\Phi}_{G} / \hat{\sigma}_{f}^{2} ;$ e) coefficient of genotypic variance: $C \hat{V}_{G}=\frac{100 \sqrt{\sigma_{G}^{2}}}{\hat{m}}$ f) variance index: ratio between the coefficient of genotypic variation $\left(C \hat{V}_{G}\right)$; and g) the coefficient of experimental variation $\left(C \hat{V}_{e}\right): I_{V}=$ $C \hat{V}_{G} / C \hat{V}_{e}=\sqrt{\hat{\Phi}_{G} / Q M R}$.

Phenotypic, genotypic, and environmental correlations between the evaluated traits were estimated by the mean products between the analyzed traits using the method described 
by Kempthorne (1966). From these analyses, the estimates of genotypic, phenotypic, and environmental covariance between pairs of traits and the coefficients of correlation were obtained, as follows:

a) Coefficient of genotypic $\frac{\operatorname{Cov}_{g}(X, Y)}{\sqrt{\hat{\sigma}_{g}^{2}(X) \cdot \hat{\sigma}_{g}^{2}(Y)}}$ correlation $\left(\mathrm{r}_{\mathrm{g}}\right)$

b) Coefficient of phenotypic $\frac{C \hat{v}_{f}(X, Y)}{\sqrt{\hat{\sigma}_{f}^{2}(X), \hat{\sigma}_{f}^{2}(Y)}}$ correlation $\left(\mathrm{r}_{\mathrm{f}}\right)$

c) Coefficient of environmental $\frac{C \hat{o}_{a}(X, Y)}{\sqrt{\hat{\sigma}^{2}(X) \cdot \hat{\sigma}^{2}(Y)}}$ correlation $\left(\mathrm{r}_{\mathrm{a}}\right)$

where $\operatorname{Côv}_{\mathrm{g}}(\mathrm{X}, \mathrm{Y}), \mathrm{Cô}_{\mathrm{f}}(\mathrm{X}, \mathrm{Y})$, and $\mathrm{Côv}_{\mathrm{a}}(\mathrm{X}, \mathrm{Y})$ are stimators of genotypic, phenotypic, and environmental covariance, respectively, between two traits $X$ and $Y ; \hat{\sigma}_{g}^{2}(X), \hat{\sigma}_{f}^{2}(X)$, and $\hat{\sigma}^{2}(X)$ are stimators of genotypic, phenotypic, and environmental variance, respectively, of trait $\mathrm{X}$; and $\hat{\sigma}_{\mathrm{g}}^{2}(\mathrm{Y}), \hat{\sigma}_{\mathrm{f}}^{2}(\mathrm{Y})$, and $\hat{\sigma}^{2}(\mathrm{Y})$ are stimators of genotypic, phenotypic, and environmental variance, respectively, of trait $Y$.

All analyses were performed using the GENES software (Cruz, 2013).

\section{RESULTS}

Significant differences were observed between genotypes for all traits $(\mathrm{P} \leq 0.01)$ (Tables 2 and 3). Coefficient of environmental variation $\left(\mathrm{CV}_{\mathrm{e}}\right)$ ranged from 3.74 to $27.36 \%$, and these limits corresponded to KTE and to RE, respectively.

Table 2. Analysis of variance for plant height (PH), number of leaves (NL), number of nodes (NNO), internode length (IL), stem diameter (SD), and leaf area (LA) for 20 coffee cultivars grown in nutrient solution with low potassium $(\mathrm{K})$ content $(1.5 \mathrm{mM})$.

\begin{tabular}{l|c|c|c|c|c|c|c}
\hline \multirow{2}{*}{ Source of variation } & \multirow{2}{*}{ d.f. } & \multicolumn{6}{|c}{ Mean square } \\
\cline { 3 - 8 } & & PH & NL & NNO & IL & SD & LA \\
\hline Block & 2 & 0.54 & 13.68 & 0.82 & 0.12 & 0.0011 & 45630.30 \\
\hline Genotype & 19 & $199.83^{* *}$ & $63.69^{* *}$ & $0.76^{* *}$ & $1.14^{* *}$ & $0.023^{* *}$ & $214012.93^{* *}$ \\
\hline Residue & 38 & 9.32 & 13.92 & 0.31 & 0.04 & 0.003 & 35390.60 \\
\hline Mean & & 43.04 & 35.28 & 11.93 & 3.61 & 0.57 & 1892.29 \\
\hline $\mathrm{CV}_{\mathrm{e}}(\%)$ & & 7.09 & 10.57 & 4.65 & 5.68 & 10.26 & 9.94 \\
\hline
\end{tabular}

**Significant at $5 \%$ probability; d.f. $=$ degrees of freedom; $\mathrm{CV}_{\mathrm{e}}=$ coefficient of variance.

Table 3. Analysis of variance for rooting efficiency (RE), absorption efficiency (KAE), translocation efficiency (KTE), biomass production efficiency (BPE), and potassium use efficiency (KUE) for 20 coffee cultivars grown in nutrient solution with low potassium $(\mathrm{K})$ content $(1.5 \mathrm{mM})$.

\begin{tabular}{|c|c|c|c|c|c|c|}
\hline \multirow[t]{2}{*}{ Source of variation } & \multirow[t]{2}{*}{ d.f. } & \multicolumn{5}{|c|}{ Mean square } \\
\hline & & $\mathrm{RE}$ & KAE & KTE & BPE & KUE \\
\hline Block & 2 & 0.00133 & 275.12 & 0.0036 & 0.201 & 0.128 \\
\hline Genotype & 19 & $0.0093 * *$ & $248.39 * *$ & $0.0036^{* *}$ & $0.411^{* *}$ & $0.496 * *$ \\
\hline Residue & 38 & 0.0002 & 87.39 & 0.0009 & 0.076 & 0.094 \\
\hline Mean & & 0.06 & 56.18 & 0.81 & 1.52 & 1.82 \\
\hline $\mathrm{CV}_{\mathrm{e}}(\%)$ & & 27.35 & 16.64 & 3.74 & 18.10 & 16.80 \\
\hline
\end{tabular}

$* *$ Significant at $5 \%$ probability; d.f. $=$ degrees of freedom; $\mathrm{CV}_{\mathrm{e}}=$ coefficient of variance. 
The phenotypic variance for all the evaluated traits had a higher contribution of genetic compared to environmental variance (Table 4). Traits with the highest phenotypic and genotypic variances were LA, KAE, PH, and NL. In contrast, the lowest values were observed for KTE, SD, BPE, and KUE.

Table 4. Estimates of phenotypic variance $\left(\hat{\sigma}_{F}^{2}\right)$, genotypic variability $\left(\hat{\Phi}_{G}\right)$, environmental variance $\left(\hat{\sigma}_{A}^{2}\right)$, coefficient of genotypic determination $\left(H^{2}\right)$, coefficient of genetic variation $(\hat{\mathrm{CVg}})$, and variation index $\left(\hat{I}_{v}\right)$ for 11 traits evaluated in 20 arabica coffee cultivars grown in nutrient solution with low potassium content.

\begin{tabular}{l|c|c|c|c|c|c}
\hline Trait & $\hat{\sigma}_{F}^{2}$ & $\hat{\Phi}_{G}$ & $\hat{\sigma}_{A}^{2}$ & $\mathrm{H}^{2}$ & $\hat{C V g}$ & $\hat{I}_{v}$ \\
\hline Plant height & 66.61 & 63.50 & 3.11 & 95.33 & 18.51 & 2.61 \\
\hline Number of leaves & 21.23 & 16.64 & 4.64 & 78.15 & 11.54 & 1.09 \\
\hline Number of nodes & 0.25 & 0.15 & 0.10 & 59.38 & 3.25 & 0.70 \\
\hline Internode length & 0.38 & 0.37 & 0.014 & 96.33 & 16.79 & 2.96 \\
\hline Stem diameter & 0.007 & 0.006 & 0.001 & 84.60 & 13.89 & 1.35 \\
\hline Leaf area & 71337.6 & 59540.8 & 11796.9 & 83.46 & 12.90 & 1.30 \\
\hline Rooting efficiency & 0.0003 & 0.0002 & 0.00009 & 70.49 & 24.41 & 0.90 \\
\hline Absorption efficiency & 82.68 & 53.55 & 29.13 & 64.77 & 13.03 & 0.78 \\
\hline Translocation efficiency & 0.001 & 0.0009 & 0.0003 & 74.55 & 3.70 & 0.99 \\
\hline Biomass production efficiency & 0.13 & 0.11 & 0.03 & 81.62 & 22.02 & 1.22 \\
\hline Potassium use efficiency & 0.17 & 0.13 & 0.03 & 81.02 & 20.05 & 1.19 \\
\hline
\end{tabular}

Most traits had coefficients of genotypic determination $\left(\mathrm{H}^{2}\right)$ above $70 \%$, with values ranging from 59.38 to $96.33 \%$ for number of nodes and internode length, respectively (Table 4). These traits also showed the lowest (0.70) and the highest (2.96) indices of environmental variation. For the coefficient of genetic variation, the number of nodes had the lowest value (3.25), while rooting efficiency had the highest (24.41).

In $100 \%$ of significant correlations between pairs of the evaluated traits, genotypic correlation was higher than phenotypic correlation, and among 55 possible combinations, environmental correlation was higher than phenotypic and genotypic correlations in only eleven of the cases (Table 5).

Table 5. Coefficients of phenotypic $\left(r_{\mathrm{p}}\right)$, genotypic $\left(\mathrm{r}_{\mathrm{G}}\right)$, and environmental $\left(\mathrm{r}_{\mathrm{E}}\right)$ correlations between plant height (PH), number of leaves (NL), number of nodes (NNO), internode length (IL), stem diameter (SD), leaf area (LA), rooting efficiency (RE), absorption efficiency (KAE), potassium translocation efficiency (KTE), biomass production efficiency (BPE), and potassium use efficiency (KUE) in 20 arabica coffee genotypes.

\begin{tabular}{|c|c|c|c|c|c|c|}
\hline Traits & & $\mathrm{RE}$ & KAE & KTE & BPE & KUE \\
\hline \multirow[t]{3}{*}{$\mathrm{PH}$} & $\mathrm{rp}$ & 0.004 & $\begin{array}{l}-0.22 \\
\end{array}$ & 0.38 & 0.05 & 0.11 \\
\hline & $\mathrm{r}_{\mathrm{G}}$ & $\begin{array}{c}-0.03 \\
\end{array}$ & -0.26 & 0.45 & -0.01 & 0.05 \\
\hline & $\mathrm{r}_{\mathrm{E}}$ & $0.28^{*}$ & -0.09 & -0.02 & $0.60^{* *}$ & $0.61^{* *}$ \\
\hline \multirow[t]{3}{*}{$\mathrm{NL}$} & $\mathrm{rp}_{\mathrm{P}}$ & $0.44^{*}$ & -0.15 & -0.25 & $0.62^{* *}$ & $0.61 * *$ \\
\hline & $r_{G}$ & $0.52^{*}$ & \begin{tabular}{|l|l|}
-0.18 \\
\end{tabular} & $\begin{array}{l}-0.44 \\
\end{array}$ & $0.67^{* *}$ & $0.64 *$ \\
\hline & $\mathrm{rE}$ & 0.18 & -0.04 & 0.36 & $0.42^{* *}$ & $0.47^{* *}$ \\
\hline \multirow[t]{3}{*}{ IL } & $\mathrm{rp}_{\mathrm{P}}$ & 0.01 & -0.02 & 0.34 & 0.06 & 0.11 \\
\hline & $\mathrm{r}_{\mathrm{G}}$ & $\begin{array}{c}-0.02 \\
\end{array}$ & -0.29 & 0.41 & 0.03 & 0.09 \\
\hline & $\mathrm{r}_{\mathrm{E}}$ & 0.25 & -0.15 & -0.02 & $0.43^{* *}$ & $0.46^{* *}$ \\
\hline \multirow[t]{3}{*}{ SD } & $\mathrm{rP}_{\mathrm{P}}$ & $0.81^{* *}$ & $-0.54 * *$ & $-0.54 * *$ & $0.91^{* *}$ & $0.91^{* *}$ \\
\hline & $\mathrm{r}_{\mathrm{G}}$ & $0.93^{* *}$ & $-0.65^{* *}$ & $-0.66^{* *}$ & $0.99^{* *}$ & $0.98^{* *}$ \\
\hline & $\mathrm{rE}_{\mathrm{E}}$ & $0.45^{* *}$ & $-0.26^{* *}$ & -0.10 & $0.49^{* *}$ & $0.54^{* *}$ \\
\hline \multirow[t]{3}{*}{ LA } & $\mathrm{r}_{\mathrm{p}}$ & $0.49^{*}$ & -0.24 & -0.18 & $0.71 * *$ & $0.72^{* *}$ \\
\hline & $\mathrm{r}_{\mathrm{G}}$ & $0.58^{*}$ & -0.30 & -0.30 & $0.74 * *$ & $0.74 * *$ \\
\hline & $\mathrm{r}_{\mathrm{E}}$ & $0.19^{* *}$ & -0.07 & 0.27 & $0.59^{* *}$ & $0.61^{* *}$ \\
\hline \multirow[t]{3}{*}{ NNO } & $r_{p}$ & -0.007 & 0.03 & 0.23 & $\begin{array}{l}-0.04 \\
\end{array}$ & -0.001 \\
\hline & $\mathrm{r}_{\mathrm{G}}$ & $\begin{array}{c}-0.08 \\
\end{array}$ & 0.004 & 0.39 & $\begin{array}{c}-0.18 \\
\end{array}$ & -0.13 \\
\hline & $\mathrm{r}_{\mathrm{E}}$ & 0.12 & 0.07 & -0.09 & $0.30^{*}$ & $0.31^{*}$ \\
\hline
\end{tabular}

**, Significant at 1 and 5\%, respectively, by bootstrap with 5000 simulations. 
$\mathrm{PH}$, IL, and NNO in the orthotropic branches had no significant phenotypic and genotypic correlations with the traits related to nutritional efficiencies for K. NL was significantly correlated with efficiencies of biomass production $\left(r_{P}=0.62\right.$ and $\left.r_{G}=0.67\right)$ and of potassium use $\left(r_{\mathrm{p}}=0.61\right.$ and $\left.\mathrm{r}_{\mathrm{G}}=0.64\right)$ (Table 5). Correlations were found between the SD and the efficiencies of rooting $\left(\mathrm{r}_{\mathrm{P}}=0.81\right.$ and $\left.\mathrm{r}_{\mathrm{G}}=0.93\right)$, of biomass production $\left(\mathrm{r}_{\mathrm{P}}=0.91\right.$ and $\left.\mathrm{r}_{\mathrm{G}}=0.99\right)$, and of potassium use $\left(\mathrm{r}_{\mathrm{P}}=0.91\right.$ and $\left.\mathrm{r}_{\mathrm{G}}=0.98\right)$. Moreover, negative and significant correlations were observed between $\mathrm{SD}$ and efficiencies of absorption $\left(\mathrm{r}_{\mathrm{P}}=-0.54\right.$ and $\mathrm{r}_{\mathrm{G}}=$ $-0.65)$ and $k$ translocation $\left(r_{P}=-0.54\right.$ and $\left.r_{G}=-0.66\right)$. Significant and positive correlations were also observed between LA and efficiencies of rooting $\left(\mathrm{r}_{\mathrm{P}}=0.91\right.$ and $\left.\mathrm{r}_{\mathrm{G}}=0.98\right)$, of biomass production $\left(\mathrm{r}_{\mathrm{P}}=0.91\right.$ and $\left.\mathrm{r}_{\mathrm{G}}=0.98\right)$, and of $\mathrm{K}$ use $\left(\mathrm{r}_{\mathrm{P}}=0.91\right.$ and $\left.\mathrm{r}_{\mathrm{G}}=0.98\right)$.

\section{DISCUSSION}

The low $\mathrm{CV}_{\mathrm{e}}$ (Tables 2 and 3) observed in this study are consistent with those in previous studies on arabica coffee in nutrient solution (Reis Jr and Martinez, 2002; Zabini et al., 2007; Pedrosa et al., 2013).

The results show genetic variability of morphological traits and efficiencies of rooting, absorption, potassium use, translocation, and biomass production, since no significant differences were observed between cultivars in an environment with low potassium availability (Tables 2 and 3). Similar results were observed between coffee genotypes in relation to morphological and nutritional efficiency traits when grown in environments under nutrientlimiting conditions (Reis Jr and Martinez, 2002; Zabini et al., 2007; Amaral et al., 2011a,b; Pedrosa et al., 2013; Moura et al., 2015). This variability is the basis for breeding programs with the goal of achieving efficient use of nutrients, and it is expressed by the phenotype, which results from the interaction of the genotype and the environment. Thus, understanding the nature and the intensity of variations of genetic and environmental origin is essential for the success of a breeding program (Dias et al., 2011). In this study, for all the evaluated traits, there was a greater contribution of genetic variance compared to environmental variance in the expression of phenotypic variability (Table 4). These results are in contrast to those observed for coffee cultivars grown in the field with adequate availability of nutrients, in which the variability for most of the growth traits had a higher influence of environmental variance (Freitas et al., 2007).

The higher the magnitude of genetic variance, the more heterogeneous are the genotypes, and the greater are the chances of selecting superior genetic material (Ferrão et al., 2008). For most traits, the coefficient of genetic variation $\left(\mathrm{CV}_{\mathrm{g}}\right)$ was higher than the $\mathrm{CV}_{\mathrm{e}}$, confirming the predominance of genetic compared to environmental components. According to Rodrigues et al. (2016), when the genetic variation is higher than environmental variation there are favorable conditions for selecting genotypes.

The use of the genetic variation coefficient enables comparison of the genetic variability between the analyzed traits. Thus, efficiencies of rooting, biomass production, and $\mathrm{K}$ use showed the highest variabilities (Table 4), indicating that they are appropriate for the selection of genotypes, which are efficient in K use. In addition, these traits presented variation indices within the magnitude considered favorable for coffee breeding (Ferrão et al., 2008), reinforcing the prevalence of genetic effects, and the possibility of obtaining genetic gains (Rodrigues et al. 2012). Moreover, these traits had high values for the coefficients of determination $\left(\mathrm{H}^{2}\right)$, which represents the heritability, and confirmed the prevalence of

Genetics and Molecular Research 15 (3): gmr.15038753 
genotypic compared to environmental variability, facilitating the successful selection of these traits (Freitas et al., 2007; Domiciano et al., 2015). High $\mathrm{H}^{2}$ estimates indicate the reliability of the phenotypic values in representing the genotypic values of the genetic materials (Ferrão et al., 2008), which allows more accurate inferences from the studied traits to the genetic material.

Evaluation of efficiencies of rooting, biomass production, and $\mathrm{K}$ use is destructive, costly, and laborious, and it often prevents the use of the genetic material in the future. Thus, finding correlation with traits that are easily measured is key for the success of selection of promising genotypes for cultivation in environments with low K, since selection efficiency can be increased with the use of correlated agronomic traits. Pedrosa et al. (2013) indicated that the discrimination of traits correlated to the differential response to the supply of a given nutrient is of great importance, since it allows evaluation and early selection of desirable genotypes. Correlation quantifies the degree of genetic and non-genetic associations between two or more traits (Hallauer et al., 2010), and these associations evaluate the possibility of indirect selection gains in correlated traits, in which the selection of traits of low heritability and/or difficult measurement and identification is more efficient when performed on traits correlated with them (Cruz et al., 2012).

Table 5 shows the estimates of coefficients of phenotypic, genotypic, and environmental correlations between morphological traits and nutritional efficiencies for K. Genotypic correlation was greater than phenotypic correlation for most pairs of traits, which favors the selection process, since the genetic effects outweighed the environmental effects on expression of the phenotype. Similar results were observed under field conditions with adequate fertilization for morphological and production traits of conilon coffee (Ferrão et al., 2008). For arabica coffee, inconsistent results were observed for the age of the plant, since in young coffee plants, there was predominance of genetic effects (Freitas et al., 2007), while in adult coffee plants, phenotypic effects were dominant (Carvalho et al., 2010). Environmental correlations for most pairs of traits were low (Table 5), demonstrating the low environmental effect in these combinations. Thus, the importance of distinguishing and quantifying the degree of genetic and environmental association is supported, since correlations with genetic causes are of inheritable nature, and may assist in breeding programs (Ferreira et al., 2003; Hallauer et al., 2010; Nogueira et al., 2012; Cruz et al., 2012).

Among the evaluated pairs of traits, only leaf area, number of leaves, and stem diameter presented correlations with efficiencies for $\mathrm{K}$ (Table 5). Leaf area and number of leaves showed positive correlations with RE, PBE, and KUE. Although these correlations were low, the increase in leaf area or the number of leaves would increase these efficiencies and vice versa. The importance of leaf area should be noted, because it indicates yield, given that photosynthesis depends on the interception of light energy and its conversion into chemical energy (Favarin et al., 2002).

SD had high, positive, and significant correlations with RE, BPE, and KUE, and negative correlations with KAE and KTE (Table 5), suggesting that the increase in SD would result in the reduction of $\mathrm{K}$ absorption and translocation. However, it would promote greater efficiency in the use of this element for root and shoot production and total use in coffee plants. Moreover, correlations between stem diameter and production of coffee and its components have been previously reported (Miranda et al., 2005; Martinez et al., 2007; Carvalho et al., 2010), which highlights the importance of this trait.

The identification of non-destructive and easily measured agronomic traits, correlated with the traits of nutritional efficiency for $\mathrm{K}$, is of great importance in breeding programs to

Genetics and Molecular Research 15 (3): gmr.15038753 
enable and accelerate the selection of superior plants. Based on our results, stem diameter has a great potential to be used in indirect selection of coffee plants that are more efficient in potassium use for crops with restriction to this nutrient. This is due to have presented genetic correlations and genetic parameters favorable to obtain gains as well as is a trait of easy measurement.

\section{Conflicts of interest}

The authors declare no conflict of interest.

\section{ACKNOWLEDGMENTS}

The authors thank Paulo César de Lima (in memorian), for their contribution in the experiments and preparation of the manuscript

\section{REFERENCES}

Amaral JFT, Martinez HEP, Laviola BG, Fernandes Filho EI, et al. (2011a). Nutrients use efficiency by coffee cultivars. Cienc. Rural 41: 621-629. http://dx.doi.org/10.1590/S0103-84782011005000027

Amaral JFT, Martinez HEP, Laviola BG, Tomaz MA, et al. (2011b). Productivity and efficiency of nutrient use in coffee crops. Coffee Sci. 6: 65-74.

Bonomo P, Cruz CD, Viana JMS, Pereira AA, et al. (2004). Evaluation of coffee progenies from crosses of Catuaí Vermelho and Catuaí Amarelo with "Hibrido de Timor" descents. Bragantia 63: 207-219.

Carvalho AM, Mendes ANG, Carvalho GR, Botelho CE, et al. (2010). Correlation between growth and yield of coffee cultivars in different regions of the state of Minas Gerais, Brazil. Pesqui. Agropecu. Bras. 45: 269-275.

Clemente JM, Martinez HEP, Alves LC and Lara MCR (2013). Effect of N and K doses in nutritive solution on growth, production and coffee bean size. Rev. Ceres 60: 279-285. http://dx.doi.org/10.1590/S0034-737X2013000200018

CONAB (Companhia Nacional de Abastecimento) (2015). Acompanhamento da safra brasileira: Café, Vol. 2 - Safra 2015, No. 3 - Terceiro Levantamento, Brasília, 1-58, setembro de 2015. Available at [http://www.conab.gov.br]. Accessed November 2015.

Cruz CD (2013). GENES: a software package for analysis in experimental statistics and quantitative genetics. Acta Sci. Agron. 35: 271-276. http://dx.doi.org/10.4025/actasciagron.v35i3.21251

Cruz CD, Regazzi AJ and Carneiro PCS (2012). Modelos biométricos aplicados ao melhoramento genético. UFV, Viçosa.

Dias NLP, Oliveira EJ and Dantas JLL (2011). Evaluation of papaya genotypes using agronomic descriptors and estimation of genetic parameters. Pesqui. Agropecu. Bras. 46: 1471-1479.

Domiciano GP, Alves AA, Laviola BG and Conceição LDHCS (2015). Genetic parameters and diversity in progenies from Macaw Palm based on morphological and physiological traits. Cienc. Rural 45: 1599-1605. http://dx.doi. org/10.1590/0103-8478cr20140909

Ernani PR, Almeida JA and Santos FC (2007). Potássio. In: Fertilidade do Solo. Sociedade Brasileira de Ciências do Solo. Viçosa, 567-601.

Favarin JL, Dourado Neto D, García Y, García A, et al. (2002). Equations for estimating the coffee leaf area index. Pesqui. Agropecu. Bras. 37: 769-773. http://dx.doi.org/10.1590/S0100-204X2002000600005

Ferrão RG, Cruz CD, Ferreira A, Cecon PR, et al. (2008). Genetic parameters in Conilon coffee. Pesqui. Agropecu. Bras. 43: 61-69.

Ferreira MAJF, Queiroz MA, Braz LT and Vencovsky R (2003). Genotypic, phenotypic and environmental correlations among agronomic traits and the consequences for watermelon breeding. Hortic. Bras. 21: 438-442. http://dx.doi. org $/ 10.1590 / \mathrm{S} 0102-05362003000300004$

Freitas ZMTS, Oliveira FJ, Carvalho SP, Santos VF, et al. (2007). Evaluation of quantitative traits related with the vegetative growth among arabica coffee cultivars. Bragantia 66: 267-275. http://dx.doi.org/10.1590/S000687052007000200010

Freitas ZMTS, Oliveira FJ, Carvalho SP, Santos VF, et al. (2009). Variability and genetic correlations in arabic coffee cultivars. Agraria 4: 122-127. http://dx.doi.org/10.5039/agraria.v4i2a1

Guimarães PTG, Nogueira FD, Malta MR, Dias KGL, et al. (2011). Coffee nutrition and its relation to the quality of coffee. Inf. Agropec. 32: 39-51.

Genetics and Molecular Research 15 (3): gmr.15038753 
Hallauer AR, Carena MJ and Miranda Filho JB (2010). Quantitative genetics in maize breeding. Springer, New York. Hoagland DR and Arnon DI (1950). The water culture method for growing plants without soils. California Agricultural Experimental Station, Berkeley.

Ivoglo MG, Fazuoli LC, Oliveira ACB, Gallo PB, et al. (2008). Genetic divergence among robusta coffe progenies. Bragantia 67: 823-831. http://dx.doi.org/10.1590/S0006-87052008000400003

Kempthorne O (1966). An introduction to the genetic statistics. J. Willey, New York.

Laviola BG, Martinez HEP, Souza RB and Venegas VHA (2006). Dynamics of N and K in leaves, flowers and fruits of arabic coffee (Coffea arabica L.) using three manuring levels. Biosci. J. 22: 33-47.

MAPA (Ministério da Agricultura, Pecuária e Abastecimento) (2012). Produção de grãos. Brasília. Available at [http:// www.agricultura.gov.br/]. Accession November 15, 2014.

Marschner H (2012). Mineral nutrition of higher plants. 2nd edn. Academic Press, New York.

Martinez HEP, Augusto HS, Cruz CD, Pedrosa AW, et al. (2007). Vegetative growth of the coffee plant (Coffea arabica L.) and its correlation with the production in narrower spacing. Acta Sci. Agron. 29: 481-489.

Miranda JM, Perecin D and Pereira AA (2005). Productivity and resistance to "Coffee Rust" (Hemiplegia vastatrix BERK. ET BR.) of F5 progenies of catuaí amarelo with the híbrido de timor. Cienc. Agrotec. 29: 1195-1200. http://dx.doi. org $/ 10.1590 / \mathrm{S} 1413-70542005000600013$

Moura WM, Soares YJB, Amaral Júnior AT, Lima PC, et al. (2015). Genetic diversity in arábica coffee grown in potassiumconstrained environment. Cienc. Agrotec. 39: 23-31. http://dx.doi.org/10.1590/S1413-70542015000100003

Nogueira APO, Sediyama T, Sousa LB, Hamawaki OT, et al. (2012). Path analysis and correlations among traits in soybean grown in two dates sowing. Biosci. J. 28: 877-888.

Nogueira FD, Silva EB and Guimarães PTG (2001). Potassium fertilization of coffee: Potassium sulfate. SOPIB, Washington.

OECD-FAO (Food and Agriculture Organization of the United Nations) (2015). Brazilian agriculture: prospects and challenges. In: OECD-FAO agricultural outlook 2015, OECD Publishing, Paris, 61-109.

Pedrosa AW, Martinez HEP, Cruz CD, Da Matta FM, et al. (2013). Growth of varieties of coffee in response to contrasting doses of zinc. Coffee Sci. 8: 295-305.

Reis Jr RA and Martinez HEP (2002). Zn addition and Zn and P uptake, translocation and utilization by coffee cultivars. Sci. Agric. 59: 537-542.

Rodrigues WN, Tomaz MA, Ferrão RG, Ferrão MAG, et al. (2012). Genetic parameters estimation in groups of Conilon coffee clones. Coffee Sci. 7: 177-186.

Rodrigues WN, Tomaz MA, Ferrão MAG, Martins LD, et al. (2016). Biometry and diversity of Arabica coffee genotypes cultivated in a high density plant system. Genet. Mol. Res. 15: 1-12.http://dx.doi.org/10.4238/gmr.15017724

Siddiqi MY and Glass ADM (1981). Utilization index: a modified approach to the estimation and comparison of nutrient utilization efficiency in plants. J. Plant Nutr. 4: 289-302. http://dx.doi.org/10.1080/01904168109362919

Zabini AV, Martinez HEP, Finger FL and Silva CA (2007). Micronutrients content and biochemistry characteristics of zinc deficient coffee (Coffea arabica L.) plants. Biosci. J. 23: 95-103.

Genetics and Molecular Research 15 (3): gmr.15038753 